\title{
A program Based on Song Lyrics and Animation Movies to Develop English Oral Reading Fluency Skills of Pre-service Teachers
}

Dr. Jehan Mahmoud El-Bassuony

Assistant Professor, Department of Curriculum\& Instruction Faculty of Education

Port Said University 


\title{
A program Based on Song Lyrics and Animation Movies to Develop English Oral Reading Fluency Skills of Pre-service Teachers
}

\author{
Dr. Jehan Mahmoud El-Bassuony \\ Assistant Professor, Department of Curriculum\& Instruction \\ Faculty of Education \\ Port Said University
}

\begin{abstract}
The purpose of this study was to investigate the effectiveness of a program based on song lyrics and animation movies in developing EFL pre-service teachers' oral reading fluency skills. The sample of the study consisted of forty seven third year English majors at Port Said Faculty of Education. The one group pre-post test quasi-experimental design was used. The instruments of the study included an oral reading fluency skills test and the songs and animation movies questionnaire. The program included ten song lyrics and five animation movies. The results of the study revealed that the proposed program significantly developed the subjects' oral reading fluency skills.
\end{abstract}

Keywords: song lyrics, animation movies, pre-service teachers, English oral reading fluency skills. 


\section{Introduction}

Oral reading fluency is a valuable skill in both native and foreign language learning contexts. It is considered a necessary dimension of proficient reading. Reading fluency is defined as efficient, effective decoding skills along with accurate, rapid, expressive, prosodic oral reading that allow students to comprehend texts (Pikulski, 2006). Not only do differences in fluency help to distinguish good readers from poor readers, but fluency is correlated to reading comprehension (Kuhn, 2005; Pikulski \& Chard, 2005). However, since many poor readers have difficulty with the components of oral reading, their fluency suffers (NICHHD, 2000; Therrien, 2004).

Literature reviews of repeated reading studies have highlighted the improvements in the fluency and comprehension of students with and without learning disabilities (Begeny, Daly III, \& Valleley, 2006; Hiebert, 2005; Therrien \& Hughes, 2008). Although repeated reading strategies proved their effectiveness in developing fluency, motivating students to repeatedly read a specific text is a challenging task. Selecting motivating passages that appeal to adult learners can help them improve their English oral reading fluency skills.

Motivating and yet intuitively simple means of increasing reading fluency, song lyrics and animation movies, have emerged in recent years. Using song lyrics from students' favorite songs as instructional materials can be very motivating to students. The rationale is that the students will be able to read the printed song lyrics because they already have stored the words in the context of the song in their auditory memories as a result of listening to the song multiple times. Hines (2010) indicates that to appeal 
and motivate adolescent students with reading disabilities and to make instruction relevant to their interests, teachers can design a readingdecoding program using lyrics from the students' favorite songs. The structure of songs, with repeating lines and a chorus, provides a natural repetition within the lyrics and repeated reading, or singing, of songs is something students do in real life (Chase, 2014).

Moreover, movies are a good example of authentic material that can be used in language teaching in order to make the learning process more entertaining, more enjoyable and possibly even somewhat easier. Mishan (2004, p. 216) emphasizes that films are designed to appeal directly and fully to people's emotions. Since the use of films in language learning has to do with affective factors, it is very important for the teacher to be able to balance between getting the students to become involved in the films while also exploiting the language learning potential of the films. Katchen (2003, p. 221) also emphasizes the authenticity of the language in films. Since the films are often made to sound natural to native speakers of the language, they thus represent authentic language. He adds that films can even substitute for the input that EFL students cannot receive outside the classroom.

Nonetheless, the rationale of using animated films instead of other genres is to bar any unexpected vulgar language, as indicated by Tatsuki (2006), since most of the animated films are ranked appropriate for all ages. Moreover, animated films can motivate young learners and it is empirically evidenced (Chuang, 2007; Yang, 2004). According to Wenger (1977, p. 15), animation offers the freest form of film-making by advancing boldly into areas where live action film cannot go. He keeps encouraging 
the use of animated films since they have much to offer for amusement and education at the same time.

Meanwhile, preservice teachers should have the opportunity to practice and develop oral reading fluency skills in order to be able to teach them to their own students. These challenges draw the attention to the significance of oral reading fluency skills and call for using different strategies to teach them. Song lyrics and animated movies, that have many advantages in the field of instruction, might hopefully improve oral reading fluency of EFL pre-service teachers in Egypt. Finally, indicators of the success of the song lyrics and animated movies -based programs in one hand and the shortage of empirical valid research in the promising area of oral reading fluency, on the other hand, provided further rationales for conducting the present study.

\subsection{Context of the problem}

The level of oral reading fluency skills of EFL pre-service teachers is very low. This is revealed by the results of previous studies (Abdel Rehim, 2001; Diab, 2015; El-Garawany, 2010; Ibrahim, 2000), the views of both their professors in Port Said Faculty of Education as well as their teaching practice supervisors. In addition, the pre-service teachers themselves complain of their low level of their oral reading fluency skills and the scarcity of opportunities to practice such skills. Therefore, there is an urgent need to develop pre-service teachers' reading fluency skills. In case they are not well prepared in these skills, their students' level will be gradually worse. In other words, EFL pre-service teachers who lack necessary oral reading fluency skills, would not be able to teach them to their future students.

\section{5}


Moreover, EFL pre-service teachers' oral reading is characterized by slow and laborious movement through the text and inappropriate application of prosodic features such as rhythm, intonation and expression. The current Egyptian English language programs do not provide students with opportunities to practice oral reading fluency skills. The non- fluent reader often lacks a desire to read orally, reads slowly, engages in a word by word reading, lacks appropriate phrasing and expression, pauses at inappropriate spots, uses sounding out words excessively, attempts at pronouncing patterns of stress and intonation not consistent with text (Abdel Rehim, 2001; El-Garawany, 2010; Seifeddin, 1991). In order for pre-service teachers to be ready for such great responsibility of teaching oral reading fluency skills in the classroom, they need adequate preparation for developing these skills. In other words, they need to master these skills to be a good model for their future students while reading English passages orally.

\subsection{Statement of the problem}

The problem of the study can be identified in the weak performance of EFL pre-service teachers concerning their English oral reading fluency skills. Hence, this study sought to find answer to the following main question:

What is the effectiveness of a program based on song lyrics and animation movies in developing EFL pre-service teachers' oral reading fluency skills?

The following sub-questions were also answered:

1- What are the oral reading fluency skills necessary to EFL pre-service teachers?

\section{6}


2- What are the song lyrics and animation movies that are motivating and interesting to EFL pre-service teachers?

3- What are the features of a program based on song lyrics and animation movies to develop EFL pre-service teachers' oral reading fluency skills?

4- How far is a program based on song lyrics and animation movies effective in developing EFL pre-service teachers' oral reading fluency skills?

\subsection{Hypotheses of the study}

Based on the discussion of literature and related studies, the following hypotheses were derived:

1- There would be statistically significant differences between the means of the scores of the subjects of the research group in the pre and post test in overall oral reading fluency skills in favor of the latter.

2- There would be statistically significant differences between the means of the scores of the subjects of the research group in the pre and post test of oral reading fluency skills (accuracy, rate, and prosody) in favor of the latter.

\subsection{Purpose of the study}

The purpose of the study was twofold:

1- Investigating the effectiveness of a program based on song lyrics and animation movies in developing English majors' overall oral reading fluency skills.

2- Determining the effect of a program based on song lyrics and animation movies on improving each oral reading fluency sub skill (accuracy, rate, and prosody) of English majors. 


\subsection{Significance of the study}

The significance of the study stems from the following considerations:

1- The test of oral reading fluency skills, the song lyrics and animation movies questionnaire and the proposed program might be beneficial to EFL researchers and curriculum designers.

2- The study might provide guidelines upon which further remedial programs may be designed to develop oral reading fluency skills.

3- EFL pre-service teachers might be able to use the program when they teach their future students different oral reading fluency skills.

\subsection{Delimitations of the study}

Since it was beyond the limits of a single study to consider a wide range of factors, this study was restricted to:

1- Selected oral reading fluency skills that are required for EFL pre-service teachers.

2- Selected song lyrics and animation movies that are interesting to EFL pre-service teachers.

3- A limited duration for implementing the program (ten weeks).

\subsection{Definition of terms}

\section{Song lyrics}

Hornby (1974, p.822) states that a song lyric is a short poem in a number of verses set to music to be sung. In its writing, the song writers or composers usually beautify the language they use by any figurative language so that the listeners will be more attracted in listening to the song.

In the present study, song lyrics are defined as words that make up a song usually consisting of verses and choruses that can be used as reading 
passages for third year EFL pre-service teachers to develop oral reading fluency skills.

\section{Animation movies}

Harrison and Hummell (2010, p. 20) refer to animation as "the rapid display of a sequence of static images that creates the illusion of movement."

An animated movie is an animated narrative that includes (or at least aspires to include) all six of Aristotle's elements of drama: a true plot, fully developed characters, a theme or message, language, songs and music, and visual spectacle. (Westfahl, 2013, p. 24).

In the present study, animation movies are defined as a genre of movies that third year EFL pre-service teachers can watch and repeatedly read the script of the movies to develop their oral reading fluency skills.

\section{Oral reading fluency skills}

According to Meyer and Felton (1999, p.284), fluency is "the ability to read connected texts rapidly, smoothly, effortlessly and automatically with little conscious attention to the mechanics of reading such as decoding."

Sargent (2003, p.20) defines oral reading fluency as a necessary dimension of proficient reading, consisting of three distinct components: effortless or automatic reading, appropriate phrasing, and use of the prosodic features of language (pitch, stress, and intonation) to appropriately convey the meaning.

In the present study, oral reading fluency is defined as the ability of EFL pre-service teachers to read orally a connected text with accuracy at a conversational rate with appropriate prosody or expression. 


\section{Review of literature and related studies}

The current study aims at developing EFL pre-service teachers' oral reading fluency skills through designing and field- testing a program based on song lyrics and animation movies. The following section sheds more light on the main variables of this study: song lyrics, animation movies and oral reading fluency skills.

\subsection{Song lyrics}

Using songs can enhance fluency as well as be enjoyable for the students. Sample (2005) proposes that adolescents are motivated by music and would enjoy using class time to learn the words of popular songs with high-frequency words and patterns. Songs naturally lend themselves to rereadings, a research-validated practice for building fluency (Therrien, 2004). Douville (2001) also argues that the rhythm and repetitive characteristics of songs have the potential to strengthen not only students' oral language development and motivation but also their reading fluency skills. In other words, using song lyrics is not only an effective way to build fluency, but also an enjoyable one.

According to Stygles (2014), carefully chosen song lyrics contain an equal opportunity to use reading strategies, decipher text to create deep meaning, and explore the author's message or perspective, within the reading workshop. Song lyrics contain universal messages, metaphorical meanings, devoid of levels and lexiles labels, offering readers an alternative approach to reading instruction. Smith (2000) validates the use of song lyrics to teach basic literacy. McLaughlin and DeVoogd (2004, p. 56) also discuss the relation between lyrics and critical literacy suggesting that students who engage in critical literacy become open-minded, active, 
strategic readers, who are capable of viewing text from a critical perspective.

Moreover, fluency instruction is typically done through oral reading. Rasinski, Homan and Biggs (2008) recommend using performance texts for lessons. Poetry, songs and song lyrics, rhetoric, plays, and other texts lend themselves most fittingly to fluency instruction. Rehearsing and performing songs and plays repeatedly is something students do willingly. They add that singing lyrics to songs is a form of reading that is nearly ideal for fluency instruction. Jensen (2005) adds that the rhythms, contrasts, and patterns of music assist the brain in encoding new information, enabling students to easily learn the lyrics to songs.

Song lyrics are regarded as appropriate instructional text vehicles, when establishing a foundation of critical awareness (Molden 2007). Alvermann (2003) revealed how student's reading engagement improved when introducing Robert Johnson's Crossroad Blues 1934 was combined with reading and discussion of similar themed poems. In her study, Chase (2104) showed that reading lyrics was highly motivating and engaging for students and it proved to have a positive impact on the student's selfperception as readers and their achievement. In addition, students felt successful reading song lyrics, they loved to learn new songs and to reread their favorites. The enjoyment they felt impacted their reading engagement and the amount of reading impacted their reading achievement.

\subsection{Animation movies}

Using movies can be an entertaining and motivating tool for learners with different skill level. Movies provide the learners with real-life language input, which may be difficult to receive in a non-English- 
speaking environment. According to Champoux (1999) and Mishan (2004), movies can be a good help in EFL teaching because of their authentic nature, the input they provide and the options they offer for persons with different types of learning strategies. Firstly, the authenticity of films can make them more interesting as a teaching material. If the topic of the film is chosen carefully the student may be able to identify to the films and thus their motivation can be better. Secondly, the input that movies provide is essential for foreign language learners, since it is not always obvious that the learners hear the language outside the classroom. Thirdly, films provide the learner with both visual and auditory stimulation which are essential for efficient learning.

Ruusunen (2011, pp. 13-14) adds other reasons for using movies in foreign language teaching. Some of these reasons are the quality and amount of input provided by movies and the several positive effects that movies have on language learning, for instance the exposure to foreign language and the entertaining aspect of films which also affects students' motivation. Also the different learning styles and the use of brain are discussed, since movies as a teaching resource affect also these factors.

Many scholars have revealed that movies used in EFL classroom can become an important part of the curriculum. This is based on the fact that movies provide exposures to real language, used in authentic settings and in the cultural context which the foreign language is spoken. They also have found that movies catch the learners' interest and it can positively affect their motivation to learn (Kusumarasdyati, 2004; Luo, 2004).

As for animation, Kobayashi and Rieber (1996, pp. 34-36) indicated that information coded both visually and verbally is more likely to be 
remembered than when each is coded alone. So, animation doubles the chance of information being stored and as a result retrieved. Animation, as he adds, provides viewers with two different visual attributes: images and motion. For scientific learning, images and motions are both essential for understanding and memorization. It has been argued that such systems (animation system) can reduce time by an average of $33 \%$ and aid the "quality" of learning, as compared with more traditional techniques (Stephenson, 1994, p.179). On the other hand, Hegarty and Sims (1994:12) indicate that animation may help students learn faster and easier. They add that this is an excellent aid for teachers to teach students difficult subjects as science and mathematics.

Different types of animation were investigatedby researchers. For example, Koroghlanian and James (2005) described how audio animation assisted the achievement, spatial ability (low and high) on reading comprehension and the attitudes' development of high school students in biology. Findings also revealed that participants who received animation spent significantly more time on the program than those who received static illustrations. Lin, Chen and Dawyer (2006) stated in their action research that computers generated animation were more effective than static visual in assisting students' retention of the more difficult and complex knowledge than they received from instructions.

On the other hand, San and Dong (2004) revealed that learning second language vocabulary through animation based context without any learning supports was inefficient for the young beginners. Kayouglu and Akbas (2011) examined whether there were differences between learning vocabulary via animation and via traditional paper based methods. Findings 
showed that although there was no significant differences between posttest of each group, there was an increase in the post-test scores of the animation group as compared to the pre test scores. Results also revealed that students have relatively positive attitudes toward using animation in vocabulary learning. They recommended that teachers use multimedia and animations as an integrative and additional way not as an alternative way.

Moreover, cartoon movies proved their effectiveness in developing language skills. Wilberschied and Peiyan (2004, p. 534) in their case study stated that watching cartoons increased students' listening comprehension skills. Sultana (2000) showed that watching cartoons has a positive effect on learning language. Children can pick many words and sentences from cartoons and use them in their real life.

Concerning animation movies, Waters (2007, as cited in Ouda, 2012, p. 15) points out that using animation films helps students developing listening, speaking and reading skills. This strategy provides an environment with native speakers, real texts and thousands of real- life images. The teacher through using animation films introduces the new vocabulary through defining them with objects, pictures and events. Thus, students acquire the new vocabulary and the language by linking them to objects and events from the real world around them. Coyner and Mccann (2004, p. 223) state that learning outside the traditional room using technologies like animations and movies through computers encourages team work for success.

According to Ouda (2012, pp. 24-25), animation movies introduces reading comprehension texts provided with motion, sounds and colors that attract the students to live with the characters and share their roles. This is a 
strong type of motivation which facilitates learning, activates learners imagination, prediction and high order thinking skills. She adds that animation provides life situation to construct a full image of information introduced. A student can read the feelings of the characters when watching them which help them understand and reflect about them. Her study revealed the effectiveness of using animation films in developing reading comprehension skills of sixth graders.

Puspitasar (2007) revealed that animation movies was effective in developing Students writing skills of narrative texts. Arikan and Taraf (2010) examined the effectiveness of authentic animated cartoons in teaching grammar and vocabulary to young Turkish learners of English. Chen (2009) investigated the pedagogical potential of using animated films in EFL teaching in the absence of satisfactory exposure to authentic language input. Findings revealed that animated films excel textbook materials in all areas except the quantities in greetings, imbalanced distribution of gender and topic choice, and the fewest quantities and varieties of examples in compliment responses.

\subsection{Oral reading fluency}

Oral reading fluency is considered one of the most important components of reading. Many researchers have focused on the definition of fluency, as a result there is a variety of definitions that focuses on different aspects of fluency. The National Reading Panel (2000, p.5) defines reading fluency as "the ability to read text quickly, accurately and with proper expression." A fluent reader can read text with speed, accuracy, and proper expression (NICHHD, 2000). Hudson, Lane and Pullen (2005) also include accuracy, rate, and prosody in their definition of fluency. Samuels (2007) 
contends that educators should consider prosody or the expression with which students read a passage.

According to Pikulski and Chard (2005, p. 510), reading fluency refers to efficient, effective word-recognition skills that permit a reader to construct the meaning of text. Fluency is manifested in accurate, rapid, expressive oral reading and is applied during, and makes possible, silent reading comprehension. Samuels (2006) not only agrees that the definition of fluency should include comprehension but also stated that measures of fluency should assess reading and comprehension at the same time. To sum up, oral reading fluency is defined as the ability to read words accurately and quickly (Fuchs, Fuchs, Hosp, \& Jenkins, 2001; Roehrig Petscher, Nettles, Hudson, \& Torgesen, 2008) with proper expression (Eldredge, 2005; Hudson et al., 2005) and comprehension (Marcell, 2007; Samuels, 2007).

Research shows that repeated readings of passages increase fluency, but that a passage should be repeatedly read for a maximum of three to four times as the gains made following more than four repeated readings cease to be significant (Therrien, 2004). Kuhn and Stahl (2003) also recommend moving beyond just fostering automatic decoding to include rhythm, expression, and prosody to help unglue students from print. Given the importance of prosody, and the fact that this element is often overlooked (Kuhn, 2005), teachers should search for ways to develop prosody that would be appealing to adolescent students.

Students need to have many opportunities to hear and read text to develop fluency. Rasinski et al. (2008) indicate that for young and struggling readers at all ages, repeated readings seems to be an essential 
method for achieving fluency. These repeated readings should be done under the guidance of a coach who will select appropriate materials, model fluent reading, provide assistance while reading, evaluate progress within and between passages, give encouragement, and celebrate success.

Modeled, assisted, and expressive reading should all be included as a part of reading fluency programs. According to Allington (2001), choral, echo, initial teacher modeled, and paired reading techniques are all methods proven to be effective in developing fluency. Additionally, these techniques lead to improvement in decoding, reading rate, prosodic reading, and comprehension of passages that the reader has not previously seen (Rasinski, 2004).

Several researchers have tested the automaticity theory and found a relationship between oral reading fluency and reading proficiency in general (Baker, Smolkowski, Katz, Fien, Seeley, Kame'enui, \& Beck, 2008; Kuhn, 2005; Morgan \& Sideridis, 2006; Riedel, 2007). Educators have used oral reading fluency as a reliable indicator of students' progress toward overall reading proficiency (Jenkins, Hudson, \& Johnson, 2007).

Concerning the relation between fluency and reading comprehension, Jones (2010) indicates that when students spend too much time trying to sound out words, they cannot comprehend what they have read by the end of a line or a page. Unless students are able to fluently decode the words in a text, they do not have sufficient attention to devote to comprehend what is read or to use metacognitive strategies to improve their comprehension.

Oral reading fluency has been correlated with overall reading competence (Fuchs et al., 2001), and studies have confirmed several strategies to improve reading fluency. When students repeatedly read a 
passage, their fluency increases (Begeny, Daly, \& Valleley, 2006; Hiebert, 2005; Martens, Eckert, Begeny, Lewandowski, DiGennaro, Montarello, 2007; Therrien \& Hughes, 2008). Although studies have found repeated readings effective, Kuhn (2005) found that wide reading is just as effective, and Morgan and Sideridis (2006) found motivational strategies more effective than repeated readings.

Three indicators of fluent reading are accuracy, rate, and prosody. These indicators will be discussed in detail.

\section{Oral reading accuracy}

Oral reading accuracy is one of the major components of oral reading fluency. It refers to "the degree to which a student's oral reading confirms to the letter-sound conventions of printed, standard English; in other words accuracy measures the student's precision in orally presenting the words in the text" (Danne, Campell, Grigg, Goodman, \& Oranje, 2005, p. 3). Hudson et al. (2005) also define accuracy as the ability to decode words correctly. They add that a reader who reads words incorrectly is unlikely to understand the author's intended message, and inaccurate word reading can lead to misinterpretation of the text.

According to Snow, Burns and Griffith (1998), the ability to obtain meaning from print depends so strongly on the development of word recognition accuracy and reading fluency, so both should be regularly assessed in the classroom, permitting timely and effective instructional response when difficulty or delay is apparent. Assessment of students' word reading accuracy can take many forms. Simply listening to oral reading and counting the number of errors per 100 words can provide invaluable information for the selection of appropriate text for various 
instructional purposes for an individual or group of students (Hudson et al., 2005). Simply accuracy is measured as a percentage of words read correctly. Cooper and Kiger (2008) present the following formula to measure accuracy:

Figure 1. Accuracy formula, adopted from Cooper and Kiger (2008, p.64)

Words read correctly

$$
\mathrm{X} 100=\ldots \ldots \%
$$

Total words read

There is a variety of accuracy errors that should be considered while reading aloud. Ekwal and Shanker (1993) and Armstrong, Campos and Johnson (2001) identify a number of reading errors such as word by word reading, incorrect phrasing, poor pronunciation, omissions, repetitions, reversals, insertions, substitutions and self-correction.

\section{Oral reading rate}

Oral reading rate is simply defined as the speed at which the student reads aloud (Danne et al., 2005, p. 3). Rate is quantified in terms of reading speed- either the number of words read correctly per minute or the length of time it takes for a reader to complete a passage. Many fluency interventions focus on increasing reading rate, because slow reading can result in weakened comprehension (Mastropieri, Leinart \& Scruggs, 1999).

According to Hudson et al. (2005, p. 704), oral reading rate comprises both word-level automaticity and the speed and fluidity with which a reader moves through connected texts. They add that timed reading can be used to measure and increase reading rate. It can allow the teacher to observe the 
number of words read correctly and the number of errors made in a given time period.

Speed of reading is one of the most widely-used indicators of fluency because it is one of the easiest to quantify. Sometimes rate of reading is improperly used as the sole measure of fluency, even though it is only one indicator of fluent reading. Speed of reading is important because increased speed (decreased reaction time) is characteristic of the development of automaticity (Logan, 1997).

Researchers indicate that oral reading fluency rates predict comprehension (Chard, Vaughn, \& Tyler, 2002; Daane et al., 2005) not because readers can read a passage quickly but because fluent readers are able to use mental energy comprehending rather than struggling with decoding (Fuchs et al., 2001). Oral reading fluency rates are important not because of how fast students read but because fluency demands little conscious attention and enables them to focus on comprehension (Samuels, 2006).

\section{Oral reading prosody}

Oral reading prosody refers to the ability to read a text orally using appropriate pitch, stress and juncture to project the natural intonation and phrasing of the spoken word upon the written text (Richards, 2005, p. 535). Farah (2006) adds that prosody is the intonation, stress and duration which lead to expressive reading. Prosody or reading with expression occurs once words become automatic. When readers read with expression they begin to group words efficiently into appropriate syntactical units such as phrases. In other words, a reader must go beyond calling words and learn to group words together in meaningful sequences (Wilger, 2008). 
Breznitz (2006) and Sargent ( 2003) who support defining fluency in terms of prosodic features, list the following items as characteristics of fluent reading: (a) lack of inappropriate hesitation, (b) appropriate phrase duration, (c) appropriate phrasing, (d) lengthening the final phrase vowel, and (e) use of pitch change at appropriate places. In addition, prosody in oral reading sound signal reading comprehension of the reader and enhance listening comprehension of thelistener. That is, prosodic readers understand what they read and make it easier for others as well (Hudson et al., 2005).

Biggs (2008, p. 88) concludes that "prosody appeared to have a direct and significant connection to reading comprehension." As automaticity, fluency, and prosody are regarded to be "the gateway to comprehension" (Rasinski, 2006, p. 704), the skill of reading fluency is an obvious factor in reading comprehension proficiency (Zugel, 2009, p. 3). Fluency is defined as not only accuracy and automaticity of individual word reading, but also prosodic rendering of the text needed for children to adequately comprehend" (Schwanenflugel, Hamilton, Kuhn, Wisenbaker, \& Stahl, 2004, p. 119).

Students' reading prosody can be measured only through observation of an oral reading of connected text. During the reading of the text teacher can listen to the student's inflection, expression and phrase boundaries such as placing vocal emphasis on appropriate words, voice tone rose and fell at appropriate points in the text and the use of punctuation to pause appropriately at phrase boundaries (Hudson et al., 2005). Several reading fluency scales include prosodic expressive reading elements. According to Hudson et al. (2005), a quantifiable scale that can be used to compare a student against himself or herself across time or between students in a class 
or school can be found in the Multidimensional Fluency Scale (Zutell \& Rasinski, 1991).

Rasinski (2004) points out that separate ratings on three distinct aspects of reading(phrasing, smoothness and pace), in addition to expression and volume, provide a more detailed evaluation of fluency than singledimension scales and are better able to capture the strengths and weaknesses of individual readers. He adds that each of the four dimensions of the Multidimensional Fluency Scale consists of a 4-point rating system. Scores range from 4 to 16 . Generally, scores below 8 indicate that fluency may be a concern. Scores of 8 or above indicate that the student is making good progress in fluency. The scale is elaborately explained in table (1). 
Table (1) The Multidimensional Fluency Scale for Reading Prosody, adopted from Zutell and Rasinski (1991, p. 215)

\begin{tabular}{|c|c|c|c|c|}
\hline Dimension & 1 & 2 & 3 & 4 \\
\hline $\begin{array}{l}\text { Expression } \\
\text { and Volume }\end{array}$ & $\begin{array}{l}\text { Reads with } \\
\text { little } \\
\text { expression or } \\
\text { enthusiasm in } \\
\text { voice. Reads } \\
\text { words as if } \\
\text { simply to get } \\
\text { them out. } \\
\text { Little sense } \\
\text { of trying to } \\
\text { make text } \\
\text { sound like } \\
\text { natural } \\
\text { language. } \\
\text { Tends to read } \\
\text { in a quiet } \\
\text { voice. }\end{array}$ & $\begin{array}{l}\text { Some } \\
\text { expression. } \\
\text { Begins to use } \\
\text { voice to } \\
\text { make text } \\
\text { sound like } \\
\text { natural } \\
\text { language in } \\
\text { some areas } \\
\text { of the text, } \\
\text { but not } \\
\text { others. Focus } \\
\text { remains } \\
\text { largely on } \\
\text { saying the } \\
\text { words. Still } \\
\text { reads in a } \\
\text { quiet voice. }\end{array}$ & $\begin{array}{l}\text { Sounds like } \\
\text { natural language } \\
\text { throughout the } \\
\text { better part of the } \\
\text { passage. } \\
\text { Occasionally } \\
\text { slips into } \\
\text { expressionless } \\
\text { reading. Voice } \\
\text { volume is } \\
\text { generally } \\
\text { appropriate } \\
\text { throughout the } \\
\text { text. }\end{array}$ & $\begin{array}{l}\text { Reads with } \\
\text { good } \\
\text { expression } \\
\text { and } \\
\text { enthusiasm } \\
\text { throughout the } \\
\text { text. Sounds } \\
\text { like natural } \\
\text { language. The } \\
\text { reader is able } \\
\text { to vary } \\
\text { expression } \\
\text { and volume to } \\
\text { match his/her } \\
\text { interpretation } \\
\text { of the } \\
\text { passage. }\end{array}$ \\
\hline $\mathrm{Phr}$ & $\begin{array}{l}\text { Monotonic } \\
\text { with little } \\
\text { sense of } \\
\text { phrase } \\
\text { boundaries, } \\
\text { frequent } \\
\text { word-by- } \\
\text { word reading. }\end{array}$ & $\begin{array}{l}\text { Frequent } \\
\text { two-and } \\
\text { three-word } \\
\text { phrases } \\
\text { giving the } \\
\text { impression } \\
\text { of choppy } \\
\text { reading; } \\
\text { improper } \\
\text { stress and } \\
\text { intonation } \\
\text { that fail to } \\
\text { mark ends of } \\
\text { sentences } \\
\text { and clauses. }\end{array}$ & $\begin{array}{l}\text { Mixture of run- } \\
\text { ons, mid- } \\
\text { sentence pauses } \\
\text { for breath, and } \\
\text { possibly some } \\
\text { choppiness; } \\
\text { reasonable } \\
\text { stress/intonation. }\end{array}$ & $\begin{array}{l}\text { Generally } \\
\text { well phrased, } \\
\text { mostly in } \\
\text { clause and } \\
\text { sentence } \\
\text { units, with } \\
\text { adequate } \\
\text { attention to } \\
\text { expression. }\end{array}$ \\
\hline
\end{tabular}


Table 1. continued

\begin{tabular}{|c|c|c|c|c|}
\hline Dimension & 1 & 2 & 3 & 4 \\
\hline Smoothness & $\begin{array}{l}\text { Frequent } \\
\text { extended } \\
\text { pauses, } \\
\text { hesitation, } \\
\text { false starts, } \\
\text { sound-outs, } \\
\text { repetitions, } \\
\text { and/or } \\
\text { multiple } \\
\text { attempts. }\end{array}$ & $\begin{array}{l}\text { Several "rough } \\
\text { spots" in text } \\
\text { where extended } \\
\text { pauses, } \\
\text { hesitations, etc.,are } \\
\text { more frequent and } \\
\text { disruptive. }\end{array}$ & $\begin{array}{l}\text { Occasional } \\
\text { breaks in } \\
\text { smoothness } \\
\text { caused by } \\
\text { difficulties } \\
\text { with } \\
\text { specific } \\
\text { words } \\
\text { and/or } \\
\text { structures. }\end{array}$ & $\begin{array}{l}\text { Generally } \\
\text { smooth } \\
\text { reading with } \\
\text { some breaks, } \\
\text { but word and } \\
\text { structure } \\
\text { difficulties are } \\
\text { resolved } \\
\text { quickly, } \\
\text { usually } \\
\text { through self- } \\
\text { correction. }\end{array}$ \\
\hline Pace & $\begin{array}{l}\text { Reads } \\
\text { slowly and } \\
\text { laboriously. }\end{array}$ & $\begin{array}{l}\text { Reads moderately } \\
\text { slowly. }\end{array}$ & $\begin{array}{l}\text { Reads with } \\
\text { an uneven } \\
\text { mixture of } \\
\text { fast and } \\
\text { slow pace. }\end{array}$ & $\begin{array}{l}\text { Consistently } \\
\text { reads at a } \\
\text { conversational } \\
\text { pace; } \\
\text { appropriate } \\
\text { pace } \\
\text { throughout } \\
\text { reading. }\end{array}$ \\
\hline
\end{tabular}

It is clear that the importance of oral reading fluency as a necessary tool for language proficiency and a basic requirement for language teachers has been emphasized. Many educationalists and researchers in different contexts tried to use different strategies to develop the varied oral reading fluency skills. Providing many opportunities for students to develop these skills is of great importance. Song lyrics and animation movies have the potential to develop oral reading fluency skills of EFL preservice teachers. 


\section{Methodology}

\subsection{Participants}

Participants of the study included forty seven EFL majors, third year students at Port Said Faculty of Education as one experimental group. The mean age of the subjects was (19.09) years. The number of females was forty three and the number of males was four.

\subsection{Design of the study}

The researcher used the one group pre-post test quasi-experimental design. Before the program, the responses of the students on oral reading fluency skills test were collected, analyzed, and scored. Then the program was carried out. The duration of the instruction was 10 weeks, two sessions per week. At the end of the instruction, the same instrument was applied to determine whether the oral reading fluency skills have improved as a result of using the song lyrics and animation movies program. The program was applied in the first term of the academic year 2014-2015.

\subsection{Instruments of the study}

Two instruments were used in this study: (available with the researcher upon request)

A- The oral reading fluency skills test.

B- The songs and animation movies questionnaire.

A- The oral reading fluency skills test

The oral reading fluency skills test was constructed in light of prior literature on oral reading fluency tests. The oral reading fluency skills test (Appendix: A) was prepared by the researcher to assess EFL pre-service teachers' oral reading fluency skills before and after the program. The final version of the test, modified according to the feedback from the three jury 
members, consisted of three reading passages; two narrative passages and a descriptive one. The two narrative passages were chosen from Gulliver's travels for Jonathan Swift and The Prisoner of Zenda for Anthony Hope. These two stories were assigned for second and third year secondary stage students respectively. The descriptive passage was selected from Zukowski/Faust, Johnston and Templin's In Context (1996) for being appropriate to students' linguistic level and background knowledge.

After selecting the three passages, two copies of each passage were prepared. An unnumbered copy for the students and a numbered one for the examiner to easily count the total words read. The three oral reading fluency skills (prosody, accuracy, and rate) were evaluated in each passage. Two raters scored the test to ensure objectivity of scoring. The researcher recorded the three passages for each student to evaluate prosody and accuracy and one minute reading of each passage to evaluate rate. As for prosody skills, students had to read the three passages and their readings were evaluated using the Multidimensional Fluency Scale for Reading Prosody adopted from Zutell and Rasinski (1991). The scale included four prosody sub skills: expression and volume, phrasing, smoothness and pace. They were evaluated on a four point rating system.

Concerning accuracy, the raters listened to the tapes and identified students' errors. The oral reading accuracy was evaluated using the formula adopted from Cooper and Kiger (2008, p.64). The number of words read correctly was divided by total words read multiplied by 100 . In addition, oral reading rate that represents the number of correct words per minute was measured using the following formula:

Total words read - errors $=$ words read correctly $($ WCPM $)$ 
The average score of the three passages was calculated then the average score of the two raters for each student was identified.

Validity of the oral reading fluency skills test

To measure test content validity, the first version of the test was presented to three EFL jury members to evaluate the test in terms of accuracy, arrangement and number of questions, difficulty level of the oral reading passages, the suitability of the test for the EFL preservice teachers' proficiency level and the appropriateness of the coding system for identifying students' errors. Their opinions were taken into consideration when preparing the final version. In addition, the calculated intrinsic validity for the oral reading fluency skills test was 0.9 . Therefore, the test was considered valid for the purposes of the current study. Reliability of the oral reading fluency skills test

The test was administered to 32 EFL pre-service teachers in Port Said Faculty of Education (not included in the main treatment of the study). Cronback's Alpha (Marascuilo, 1971; Payne, 1997) was used to calculate the reliability coefficient of the test. The calculated reliability coefficient was 0.89 . Thus, the oral reading fluency skills test is reliable to be used in assessing EFL pre-service teachers' oral reading fluency skills.

Reliability of the scale was estimated by calculating the correlation coefficient between two raters' scoring of the test of $32 \mathrm{EFL}$ prospective teachers at Port Said Faculty of Education (not included in the main treatment). The correlation coefficient between the raters' scores is 0.82 . The scale was then used to grade the subjects' responses in the pre and post test. 
B- The songs and animated movies questionnaire

This questionnaire was employed to determine the ten song lyrics and five animated movies to be used in the program. The songs included in the questionnaire were selected based on their suitability to students' linguistic level and social values. The titles of animated movies were selected from the top-selling box offices and also referenced with well-known movie awards to ensure the content quality. The initial songs and animated movies questionnaire (Appendix: B) included two main categories (twenty songs and ten animated movies) with five levels of being interesting (not interesting, less interesting, not sure, interesting, very interesting). It was submitted to a sample of third year EFL preservice teachers (30) to determine how far the songs and animated movies included in the questionnaire were interesting and motivating. Moreover, the students were asked to add any songs or animated movies they considered interesting. After analyzing the responses of the students, the researcher selected ten songs and five animated movies that had the highest percentage of agreement by the students (Appendix: C). 


\subsection{The program}

* Aim of the program

This song lyrics and animation movies based program aimed at developing EFL pre-service teachers' oral reading fluency skills.

* Objectives of the program

By the end of this program, EFL pre-service teachers were expected to:

- read orally the selected song lyrics and animation movies with prosody.

- read orally the selected song lyrics and animation movies accurately.

- read orally the selected song lyrics and animation movies at a conversational rate.

* Content and duration of the program

In designing the program (Appendix: D), ten song lyrics and five animated movies were used as oral reading passages to develop prosody, accuracy and rate. As a result, the program comprised twenty sessions and each session took ninety minutes. Students had two sessions per week. The song lyrics were used in the first ten sessions and the animated movies were practiced in the following ten sessions (two sessions for each movie). The song lyrics and animated movies were downloaded from YouTube. At the end of each session the new song or animation movie was given to students on their mobile phones using Bluetooth. They had also hard copies of the song lyrics or movies to practice reading them while listening to their mobile phones at home.

Moreover, two repeated reading strategies were used: a) paired reading, b) performance reading. In paired reading, pairs of students took turns reading and rereading the same song or movie to each other providing support and guidance. In performance reading, a group of students 
practiced reading a text to prepare for a performance of a song or part of a movie. It helped them gain proper and expressive reading. In addition, the procedures followed in each session were as follows:

\section{Procedures of the session}

- T. discussed the title of the song/movie, the feelings of the singer/main characters and the main ideas.

- T. explained points of difficulty concerning pronunciation of new words and expression.

- T. asked students to select their pairs. Partner 1 read the first stanza in the song/assigned part in the movie. Partner 2 read the same part.

- Ss repeated the previous step until the song/movie was completed.

- During listening to their pairs, students used a partner's log (Appendix: E) to record their partners' reading errors. They had to correct their partners when an error was made. They also had to determine their reading rate (number of words read correctly per minute) and write it in their logs.

- T. observed students to clarify any confusing parts in their readings or problems in recording errors and reading rate.

- T. asked pairs/groups of students to perform the song/part of a movie. They have to imitate the singer/character while reading concerning expression, volume, phrasing, smoothness and pace.

- T. provided remedial exercises to overcome repeated errors.

- T. gave the new song/ animation movie to students on their mobile phones using Bluetooth. They had also hard copies of the song lyrics/ movies to practice reading them while listening to their mobile phones at home. 
- Ss had to record parts of their reading of song lyrics or animation movies as a home assignment.

* Evaluation

The evaluation techniques used in the program consisted of both quantitative and qualitative evaluation. Quantitative evaluation was divided into formative and summative evaluation:

- Formative evaluation

It was used for the purpose of assessing the progress of EFL preservice teachers in developing oral reading fluency skills as well as providing the necessary feedback that can help them monitor their own progress. They had to record parts of their reading of song lyrics or animation movies as a home assignment and the teacher collected some of these records at the end of each session and wrote comments about them. The students also had to compare their initial reading at home with their final reading with their partners concerning number of word errors and rate. - Summative evaluation

It included the administration of the pre-post oral reading fluency skills test to investigate the effectiveness of the program in developing English oral reading fluency skills of the research group.

As for qualitative evaluation, in every session the teacher used to collect some of the students' partner's logs to encourage them. They used partner's log to help them assess their progress in the number of word errors and reading rate. The teacher also kept written records for students. These records included the date and the comments of the teacher on students' oral reading during performance reading concerning their oral reading prosody.

\section{1}




\section{Results and discussion}

\subsection{Results}

The results of the study will be presented in terms of the study hypotheses as follows:

Hypothesis one: There would be statistically significant differences between the means of the scores of the subjects of the research group in the pre and posttest in overall oral reading fluency skills in favor of the latter.

The " $t$ " test for paired samples was used to find out the extent to which subjects' oral reading fluency skills have developed throughout the program. The results of the " $t$ " test proved to be statistically consistent with the above stated hypothesis as shown in table (2).

Table (2)

" $t$ " test of the pre and post oral reading fluency test

\begin{tabular}{|c|c|c|c|c|c|c|}
\hline Skills & & $\mathbf{N}$ & Mean & SD & T-test & $\begin{array}{l}\text { P- } \\
\text { value }\end{array}$ \\
\hline \multirow[b]{2}{*}{ Prosody } & Pre-test & \multirow[b]{2}{*}{47} & 5.34 & 1.15 & \multirow[b]{2}{*}{13.30} & \multirow[b]{2}{*}{0.001} \\
\hline & $\begin{array}{l}\text { Post- } \\
\text { test }\end{array}$ & & 9.79 & 1.96 & & \\
\hline \multirow[b]{2}{*}{ Rate } & Pre-test & \multirow[b]{2}{*}{47} & 94.98 & 6.49 & \multirow[b]{2}{*}{13.19} & \multirow[b]{2}{*}{0.001} \\
\hline & $\begin{array}{l}\text { Post- } \\
\text { test }\end{array}$ & & 115.30 & 7.19 & & \\
\hline \multirow[b]{2}{*}{ Accuracy } & Pre-test & \multirow[b]{2}{*}{47} & 74.85 & 4.34 & \multirow[b]{2}{*}{14.81} & \multirow[b]{2}{*}{0.001} \\
\hline & $\begin{array}{l}\text { Post- } \\
\text { test }\end{array}$ & & 87.68 & 4.30 & & \\
\hline \multirow{2}{*}{$\begin{array}{l}\text { oral reading } \\
\text { fluency test }\end{array}$} & Pre-test & \multirow[b]{2}{*}{47} & 175.17 & 7.59 & \multirow[b]{2}{*}{21.28} & \multirow[b]{2}{*}{0.001} \\
\hline & $\begin{array}{l}\text { Post- } \\
\text { test }\end{array}$ & & 212.77 & 8.41 & & \\
\hline
\end{tabular}

As shown in table (2), the estimated "t" value for the overall oral reading fluency skills was significant at 0.001 level. This indicates that there are statistically significant differences between the mean scores of the 
subjects in the pre-post test in favour of the post test score. Therefore, there is enough evidence to support hypothesis one.

Hypothesis two: There would be statistically significant differences between the means of the scores of the subjects of the research group in the pre and the post test of oral reading fluency skills (accuracy, rate, and prosody) in favor of the latter.

In order to verify the validity of this hypothesis, " $t$ " test for paired samples was used. The results proved that there were statistically significant difference between the pre- post oral reading fluency test mean score of the subjects in the three sub skills of oral reading fluency. The results of the " $\mathrm{t}$ " test proved to be statistically consistent with the above stated hypothesis as shown in table (2).

To sum up, Table (2) shows that there were statistically significant differences at 0.001 level between the mean scores of the subjects in the pre-post reading fluency in favour of the post reading fluency scores for the overall oral reading fluency as well as the three sub skills.

\subsection{Discussion}

Concerning the overall oral reading fluency skills, the positive results of this study support the findings of other studies like Chase (2014), ElGarawany (2010) and Waters (2007). This result might be due to the fact that watching song lyrics and animation movies is fun. Students were motivated to repeatedly read the same material because they enjoyed it. They stored the lines of the song or animation movie in their auditory memories as a result of listening to it several times. So, it was much easier for them to read these lines orally. 
In addition, students' progress in oral reading accuracy might be attributed to certain factors: (a) the paired repeated reading strategy provided an opportunity for students to correct each other's errors in a nonthreatening environment and to reflect on their reading improvement; (b) using partner's log helped them monitor their progress with the help of each other's guidance and support; (c) the constant exposure to print as well as the excessive practice led to a decrease in the number of oral reading errors; (d) at home, students watched song lyrics and animated movies and listened to words and how they were pronounced by a native speaker. Whenever they were not sure of the pronunciation of a word they listened to it again. This helped them correct their errors and pronounce words accurately.

Moreover, students' progress in oral reading rate might be due to a number of factors. First, listening to native speakers helped them to chunk words and increase the number of words read at a time. Second, the correct words increased as students made fewer errors after reading several times. Third, students began to exert less effort in pronouncing the words. Fourth, students enjoyed measuring time, counting the words, subtracting the errors, calculating their speed and observing their progress. Fifth, students were competitive in achieving better scores in oral reading rate.

Finally, students' progress in oral reading prosody might be due to: (a) watching and listening to songs and animation movies that helped students to apply the prosodic features of English in their readings such as expression and phrasing; (b) the fact that when the number of word errors decreased, their reading rate increased and they were better able to focus on expression; (c) using performance reading strategy that encouraged 
students to imitate singers and actors in animation movies to make a good performance for their colleagues.

\section{Conclusions}

It is important to mention that the results of the study are limited by the sample size, the characteristics of the subjects, the length of the study and the selected song lyrics and animation movies used in the study. Within these limitations, it can be concluded that the program based on song lyrics and animation movies is effective in developing overall oral reading fluency skills as well as the three sub skills (accuracy, rate, and prosody) of EFL pre service teachers. These results support the indicators of success the song lyrics and animation movies studies revealed in other contexts (Chase, 2014 ; Ouda, 2012; Waters, 2007). To sum up, the results of the study can provide the basis for many other treatments based on song lyrics and animation movies to develop different skills in different language learning contexts.

\section{Recommendations}

Based on the results of this study and the above mentioned conclusions, the following recommendations seem pertinent:

- Pre-service teachers should be encouraged to use song lyrics and animation movies to develop their own English oral reading fluency skills as well as their future students' skills.

- Oral reading fluency instruction should be a part of English reading courses in Egyptian Universities.

- The song lyrics and animation movies based program should be used in teaching oral reading fluency skills to school students.

\section{5}


- More attention should be given to English oral reading fluency skills in Egyptian schools.

- Song lyrics and animation movies should be included in university courses as authentic and motivating reading materials.

- Many opportunities should be provided to practice partner and performance reading strategies to master fluency skills.

\section{Suggestions for further research}

Within the limitations of the present study as well as the results being achieved, the following areas are suggested for further research:

1- Conducting studies to use programs based on song lyrics and animation movies with EFL learners at various educational levels and in different language learning contexts.

2- More research is needed to examine the effectiveness of programs based on song lyrics and animation movies in developing different language skills.

3- More research is needed to examine different programs that develop oral reading fluency skills of EFL pre service teachers.

4- Conducting studies to examine different programs that could improve oral reading accuracy, rate and prosody of EFL pre service teachers. 


\section{References}

Abdel Rahim, S. (2001). The effect of communication strategies and risktaking on oral fluency. Occasional papers issued by C.D.E.L.T, 33, 200-231

Allington, R. (2001). What Really Matters for Struggling Readers: Designing Research Based Programs. New York: AddisonWesley.

Alvermann, D. (2003). Seeing themselves as capable and engaged readers: Adolescents and re/mediated instruction. Naperville, IL: Learning Point Associates.

Arikan, A., \& Taraf, H. (2010). Contextualizing young learners' English lessons with cartoons: Focus on grammar and vocabulary. Educational Leadership, 12(2), 5212-5215.

Arone, A., \& Arone, A. (2002). Statistics for the behavioral and social sciences: $\quad$ A brief course. (2nd ed.). Upper Saddle River, NJ: Pearson Educational, Inc.

Baker, S., Smolkowski, K., Katz, R., Fien, H., Seeley, J., Kame’enui, E., \& Beck, C. (2008). Reading fluency as a predictor of reading proficiency in low- performing, high-poverty schools. School Psychology Review, 37(1), 18-37.

Begeny, J., Daly III, E., \& Valleley, R. (2006). Improving oral reading fluency through response opportunities: A comparison of phrase drill error correction with repeated readings. Journal of Behavioral Education, 15(4), 229-235.

Breznitz,Z. (2006). Fluency in reading: synchronization of processes. Mahwah NJ : Lawrence Erbium Associates 
Champoux, J. (1999). Film as a teaching resource. Journal of Management Inquiry, 8(2), 240-251.

Chard, D., Vaughn, S. \& Tyler, B. (2002). A synthesis of research on effective interventions for building fluency with elementary students with learning disabilities. Journal of Learning Disabilities, 35, 386-406.

Chase, M. ( 2014). Using song lyrics to develop reading skills. Galileo Inquiry Project. Retrieved June 14, 2014, from http://michellechaseportfolio.weebly.com/uploads/3/1/2/4/31245 933/using_song_lyrics_to_develop_reading_skills.pdf

Chen, B. (2009). The use of animated films in EFL teaching: A comparison of their pedagogical potential with textbook materials in Taiwanese elementary schools. Unpublished master's thesis, National Taipei University of Education, Taiwan.

Chuang, H. C. (2007). The influence of infusing English cartoon movie into teaching on elementary school children's English achievement and motivation. Unpublished master's thesis, National University of Tainan, Taiwan.

Coyner, S. Mccann, P. (2004). Advantages and challenges of teaching an electronic environment. International Journal of Instruction Media, 31(3), 53.

Daane, M.,Campell, J., Grigg,W., Goodman, M.\& Oranje, A.(2005). Fourth-grade students reading aloud: NAEP 2002 special study of oral reading. Washington, DG: U.S. Department of education Sciences. Retrieved November 5, 2014, from http://nces.ed.gov/nationsreportcard/pdf/studies/2006469.pdf 
Douville, P. (2001). Using songs and chants as a source of predictable text. Preventing School Failure, 45(4), 187-8.

El-Garawany, M. (2010).The effects of repeated reading strategies on developing oral reading fluency and reading comprehension among EFL prospective teacher. Unpublished master's thesis, Minufiya University.

Eldredge, J. (2005). Foundations of fluency: An exploration. Reading Psychology, 26(2), 161-181.

El-matarawy, A. (1998). Using cooperative learning techniques to develop English oral language fluency of adult learner. Unpublished doctoral dissertation, faculty of education, Ain shams university.

Farah, M. (2006). The efficiency of oral reading interventions on transitional readers' fluency. Unpublished doctoral dissertation, Oakland University.

Fuchs, L., Fuchs, D., Hosp, M., \& Jenkins, J. (2001). Oral reading fluency as an indicator of reading competence: A theoretical, empirical, and historical analysis. Scientific Studies of Reading, 5(3), 239256.

Harrison, H., \& Hummell, L. (2010). Incorporating animation concepts and principles in STEM education. Technology Teacher, 69(8), 2025.

Hegarty, M., \& Sims, V. (1994). Individual differences in mental animation during mechanical reasoning. Memory \& Cognition, 22, 411-430.

Hiebert, E. (2005). The effects of text difficulty on second graders' fluency development. Reading Psychology, 26(2), 183-209. 
Hines, S. (2010). Name that word: Using song lyrics to improve the decoding skills of adolescents with learning disabilities. Teaching Exceptional Children, 43(1), 16-21.

Hornby. (1974). The new Grolier Webster international dictionary of current English. New York, oxford University Press.

Hudson, R., Lane, H., \& Pullen, P. (2005). Reading fluency assessment and instruction: What, why and how? The Reading Teacher, 58(8), 702-14.

Jenkins, J., Hudson, R., \& Johnson, E. (2007). Screening for at-risk readers in a response to intervention framework. School Psychology Review, 36(4), 582-600.135. 122

Jensen, E. (2005). Top tunes for teaching: 977 song titles and practical tools for choosing the right music every time. Thousand Oaks, CA: Corwin.

Jones, K. (2010). The relationship between oral reading fluency and reading proficiency. Unpublished doctoral dissertation, Walden University.

Katchen, J. (2003). Teaching a listening and speaking course with DVD films: Can it be done? In H. C. Liou, J. E. Katchen, and H. Wang (Eds.), Lingua Tsing Hua. Retrieved on July 19, 2014, from http://mx.nthu.edu.tw/ katchen/professional/festschrift.htm

Kobayashi ,O. \& Rieber, L. (1996). A historical review of visualization in human cognition. ETR\&D, 43(1), 45-56.

Koroghanian, C. \& James, D.(2005). The effect of audio and animation multimedia audio. Journal of Education Multimedia and Hypermedia, 13(1), 23. 
Koyooglu, M. \& Akbas, R. (2011). A small scale experimental study: Using animations to learn vocabulary. The Turkish Online Journal of Educational Technology,10(2), 15-30.

Kuhn, M. (2005). A comparative study of small group fluency instruction. Reading Psychology, 26(2), 127-146.

Kuhn, M. \& Stahl, S. (2003). Fluency: A review of developmental and remedial practices. Journal of Educational Psychology, 95, 3-22.

Kusumarasdyati, T. (2004). Listening, viewing and imagination: Movies in EFL classes. 2nd International Conference on Imagination and Education Vancouver, Canada. Retrieved June10, 2014, from http://eoicinecadiz2011.wikispaces.com/file/view/movies+in+efl + classes.pdf

Lin, H. Chen, T. Dwyer, M.(2006). Effect of static visuals and computer generated animations in facilitating immediate and delayed achievement in EFL classroom. Foreign Languages Annals, 39(2), 203-207.

Luo, J. J. (2004). Using DVD films to enhance college freshmen's English listening comprehension and motivation. Unpublished master's thesis, National Tsing Hua University, Hsinchu. Taiwan, R.O.C

Marascuilo, L. (1971). Statistical methods for behavioral science research. USA: McGraw-Hill Book Company

Marcell, B. (2007). Traffic light reading: Fostering the independent usage of comprehension strategies with informational text. Reading Teacher, 60(8), 778-781.

Martens, B., Eckert, T., Begeny, J., Lewandowski, L., DiGennaro, F., Montarello, S. (2007). Effects of a fluency-building program on 
the reading performance of low-achieving second and third grade students. Journal of Behavioral Education, 16(1), 38-53.

McLaughlin, M., \& DeVoogd, G. (2004). Critical literacy as comprehension: Expanding reader response. Journal of Adolescent \& Adult Literacy, 48(1), 52-62.

Mishan, F. 2004. Designing authenticity into language learning materials. Bristol: Intellect Books. Retrieved June 11, 2014, from http://site.ebrary.com/lib/jyvaskyla/Doc?id=10073901\&ppg=1

Molden, K. (2007). Critical literacy, the right answer for the reading classroom: Strategies to move beyond comprehension for reading improvement. Reading Improvement, 44(1), 50.

Morgan, P. \& Sideridis, G. (2006). Contrasting the effectiveness of fluency interventions for students at risk for learning disabilities: A multilevel random coefficient modeling meta-analysis. Learning Disabilities Research and Practice, 21(4), 191-210.

National Institute of Child Health and Human Development. (NICHHD). (2000). Report of the National Reading Panel. Teaching children to read: An evidence-based assessment of the scientific research literature on reading and its implications for reading instruction (NIH Publication No. 00-4769). Washington, DC: Author.

National Reading Panel. (2000). About the NRP - Charge. Retrieved June15, 2014 , from http://www.nationalreadingpanel.org/NRPAbout/Charge.htm

Ouda, N. (2012). The effect of using animation on 6th graders' attitudes and comprehension of short story in Gaza governmental schools. Unpublished master's thesis, The Islamic University - Gaza. 
Payne, D. (1997). Applied educational assessment. CA: Wadsworth Publishing Company.

Pikulski, J., \& Chard, D. (2005). Fluency: Bridge between decoding and reading comprehension. Reading Teacher, 58, 510-519.

Pikulski, J. (2006). Fluency: A develop-mental and language perspective. In S.J Samuels and A.E. Farstrup (eds). What Research Has to Say About Fluency Instruction. London: International Reading Association.

Puspitasari, R. (2007). The use of animation movies for developing students' writing skill of narrative text. Semarang: Universitas Negeri Semarang.

Rasinski, T. (2004), Creating Fluent Readers. Educational Leadership, 61(6), 46-51.

Rasinski, T. (2006). Reading fluency instruction: Moving beyond accuracy, automaticity, and prosody. The Reading Teacher, 59 (7), 704-6.

Rasinski, T., Homan, S., \& Biggs, M. (2008), Teaching reading fluency to struggling readers - method, materials, and evidence. Retrieved June 9, 2014, from http://www.coedu.usf.edu/main/ departments /ce/homan/docs/rasinski,\%20homan\%20biggs.515.106[1].pdf

Riedel, B. (2007). The relation between DIBELS, reading comprehension, and vocabulary in urban first-grade students. Reading Research Quarterly, 42(4), 546-562.

Roehrig, A., Petscher, Y., Nettles, S., Hudson, R., \& Torgesen, J. (2008). Accuracy of the DIBELS oral reading fluency measure for predicting third grade reading comprehension outcomes. Journal of School Psychology, 46(3), 343-366. 
Ruusunen, V. (2011). Using movies in EFL teaching: The point of view of teachers. Unpublished master's thesis, University of Jyväskylä.

Sample, K. (2005). Promoting fluency in adolescents with reading difficulties. Intervention in School and Clinic, 40 (4), 243-6.

Samuels, S. (2006). Toward a model of reading fluency. In S. J. Samuels \& A. E. Farstrup (Eds.), What research has to say about fluency instruction (pp. 24-46). Newark, DE: International Reading Association.

Samuels, S. (2007). The DIBELS tests: Is speed of barking at print what we mean by reading fluency? Reading Research Quarterly, 42(4), 563-566.

San, Y. \& Dong, Q. (2004). An experiment on Supporting Children's English Vocabulary Learning in Multimedia. Context Computer Assisted Language Learning, 17(2), 131-147

Sargent , S. (2003) .Oral Reading Fluency: A predictor Of Reading Proficiency In Fifth Grade Students? Unpublished doctoral dissertation, Oklahoma State University.

Schwanenflugel, P., Hamilton, A., Kuhn, M., Wisenbaker, J., \& Stahl, S. (2004). Becoming a fluent reader: Reading skill and prosodic features in the oral reading of young readers. Journal of Educational Psychology, 1, 119-129.

Smith, J. (2000). Teaching reading. The Reading Teacher, 53(8), 646-649.

Stephenson, S. D. (1994). The use of small groups in computer-based training: A review of recent literature. Computers in Human Behavior, 10, 243-259. 
Stygles, J. (2014). Building schema: Exploring content with song lyrics and strategic reading. The Language and Literacy Spectrum, 24, 101113.

Sultana, S. (2000). Cartoons as an elementary source of learning English (L2) for the young learners. ELT Weekly. 33(3), 53-66.

Tatsuki, D. (2006). What is authenticity? Shizuoka, Japan: Tokai University College of Marine Science, 1-12. Retrieved October 6, 2014, from http://jalt.org/pansig/2006/HTML/Tatsuki.htm

Therrien, W. J. (2004). Fluency and comprehension gains as a result of repeated reading: A meta-analysis. Remedial and Special Education, 25(4), 252-61.

Therrien, W., \& Hughes, C. (2008). Comparison of repeated reading and question generation on students' reading fluency and comprehension. Learning Disabilities: A Contemporary Journal, 6(1), 1-16.

Wegner, H. (1977). Teaching with film. Bloomington, Indiana: The Phi Delta Kappa Educational Foundation.

Westfahl, T. (2013). A sense-of-wonderful century: Explorations of science fiction and fantasy films. Retrieved July 19, 2014, from https://www.sfsite.com/gary/ww-misc-animated01.htm

Wilger, M. (2008). Reading fluency: A bridge from decoding to comprehension. London: Cognitive Scientist Auto skill International Inc.

Willberschied, L. \& Peiyan, M. (2004). Effect of Using Photos from Authentic Video As Advance Organizers on Listening 
Comprehension in an EFLEs Chinese Class. Foreign language Annals. 37(4), 534.

Yang, L. (2004). A study of the effect in listening comprehension after watching the cartoon of two various subtitles. Unpublished master's thesis, National Taipei University of Education, Taiwan.

Zutell, J. \& Rasinski, T. (1991).Training teachers to attend to their students' oral reading fluency. Theory Into Practice, 30, 211-217.

Zukowsk-Faust, J., Johnston, S. \& Templin, E. (1996). In context. 2nd Edition. New York: Harcourt Brace. 